\title{
Identification of risk factors influencing Clostridium difficile prevalence in middle-size dairy farms
}

\author{
Petra Bandelj ${ }^{*}$, Rok Blagus ${ }^{2}$, France Briski ${ }^{3}$, Olga Frlic ${ }^{4}$, Aleksandra Vergles Rataj ${ }^{1}$, Maja Rupnik ${ }^{5,6,7}$, \\ Matjaz Ocepek and Modest Vengust ${ }^{1}$
}

\begin{abstract}
Farm animals have been suggested to play an important role in the epidemiology of Clostridium difficile infection (CDI) in the community. The purpose of this study was to evaluate risk factors associated with C. difficile dissemination in family dairy farms, which are the most common farming model in the European Union. Environmental samples and fecal samples from cows and calves were collected repeatedly over a 1 year period on 20 mid-size family dairy farms. Clostridium difficile was detected in cattle feces on all farms using qPCR. The average prevalence between farms was $10 \%(0-44.4 \%)$ and $35.7 \%$ (3.7-66.7\%) in cows and calves, respectively. Bacterial culture yielded 103 C. difficile isolates from cattle and 61 from the environment. Most $C$. difficile isolates were PCR-ribotype 033. A univariate mixed effect model analysis of risk factors associated dietary changes with increasing $C$. difficile prevalence in cows $(P=0.0004)$; and dietary changes $(P=0.004)$, breeding Simmental cattle $(P=0.001)$, mastitis $(P=0.003)$ and antibiotic treatment $(P=0.003)$ in calves. Multivariate analysis of risk factors found that dietary changes in cows $(P=0.0001)$ and calves $(P=0.002)$ increase $C$. difficile prevalence; mastitis was identified as a risk factor in calves $(P=0.001)$. This study shows that $C$. difficile is common on dairy farms and that shedding is more influenced by farm management than environmental factors. Based on molecular typing of $C$. difficile isolates, it could also be concluded that family dairy farms are currently not contributing to increased CDI incidence.
\end{abstract}

\section{Introduction}

Clostridium difficile is a spore forming Gram positive anaerobe, which causes hospital and antimicrobial-associated intestinal disease in humans and some animal species. The incidence, severity, and recurrence rates of $C$. difficile infections in humans are increasing [1-6]. Recent prevalence studies suggested that farm animals can be the source for human infection [7-10], which has not been scientifically confirmed [11].

Antibiotic treatment, hospitalization, change of diet and neonatal period were suggested risk factors for $C$. difficile perpetuation in farm and companion animals [12-21]. Most studies investigating the epidemiology

\footnotetext{
*Correspondence: petra.bandelj@vf.uni-lj.si

${ }^{1}$ Veterinary faculty, University of Ljubljana, cesta v Mestni log 47,

1115 Ljubljana, Slovenia

Full list of author information is available at the end of the article
}

of $C$. difficile in bovines were performed on large scale intensive dairy and/or beef operations [8, 11, 22, 23], which is not reflective of the European agriculture. These studies mostly investigated the risk of age $[11,22,23]$ or age and antibiotic use [8] for $C$. difficile shedding with feces, many times excluding several possible farm management and environment related risk factors [24].

Family farming is the most common operating farming model in the European Union (EU) [25]. It is strongly supported by the European commission and the majority of member EU states, because of its positive contribution to the socio-economic and environmental sustainability of rural areas [25]. They directly supply the local community and the market in general with products of animal and non-animal origin, within a rich epidemiological environment comprised of people, pet animals, farm animals, wild animals and vermin. To date, there are no studies investigating the epidemiology of $C$. difficile in 
such an environment. The purpose of this study was, therefore, to determine the prevalence of $C$. difficile, to characterize $C$. difficile isolates and to determine risk factors for $C$. difficile perpetuation within the most common operational farming model in Europe.

\section{Materials and methods}

This study underwent ethical review and was given approval by the National Animal Care Committee at the Ministry of Agriculture, Forestry and Food-Veterinary administration.

\section{Animal samples}

Twenty family dairy farms (Table 1) located in the Slovenian Prealps were included in this study. The average milk yield was $6605.2 \mathrm{~L}$ milk/cow/year (3727.32-8876.64 L milk/cow). Diseases recorded and treated on the farms were mostly mastitis, pneumonia, diarrhea, displaced abomasum or other gastrointestinal diseases, ketosis and endometritis/metritis. During the study every herd was checked for infectious diseases, such as paratuberculosis, listeriosis, bovine viral diarrhea and infectious bovine rhinotracheitis (Table 1).

Products from farms included in this study are mostly sold within the local community, whereas surplus milk and meat are sold to different dairy and meat processing plants in Slovenia, Austria and north-east Italy.

Calves were categorized into three age groups at the time of each sampling (age group one: 0-21 days; age group two: 22-56 days; age group three: 57-180 days), based on their nutritional and digestive physiology [26]. Feces were sampled individually from cows and calves under the age of 6 months in exactly 2 week intervals for a period of 1 year (27 sampling days from November, 2011-November 2012). For all the farms, the same sampling protocol was followed. Samples were taken from the rectum using clean latex gloves (Shield, UK). Cow and calf fecal samples from each farm were pooled separately in the laboratory within $24 \mathrm{~h}$ after collection: One gram of fecal sample from each individual was used. Pooled samples were then diluted with sterile saline solution in a 1:3 ratio. The aliquot of $2 \mathrm{~mL}$ of every pooled sample, and individual samples from all calves were stored in $2 \mathrm{~mL}$ sterile vials (Eppendorf Tubes ${ }^{\circledR}$, Germany) at $-70{ }^{\circ} \mathrm{C}$ for future analysis.

Heifers and bulls over 6 months of age were excluded from the study because of their limited contact with humans. They are not subjected to significant stress factors of production animals and are usually not used to human handling.

Table 1 Dairy farm characteristics and health status

\begin{tabular}{|c|c|c|c|c|c|c|c|c|}
\hline \multicolumn{5}{|c|}{ Farm characteristics } & \multicolumn{4}{|l|}{ Health status } \\
\hline Farm & Housing type & Cattle type & Farm location & No. dairy cows & Paratuberculosis & Listeriosis & BVD & IBR \\
\hline Farm 1 & Free + Grazing & Holstein-Friesian & Rural & $17-21$ & - & - & - & - \\
\hline Farm 2 & Tie & Holstein-Friesian & Rural & $11-13$ & - & - & - & + \\
\hline Farm 3 & Tie & Holstein-Friesian & Village & $10-13$ & - & - & - & + \\
\hline Farm 4 & Tie & Holstein-Friesian & Village & $23-27$ & - & + & - & - \\
\hline Farm 5 & Free & Holstein-Friesian & Village & $21-24$ & - & + & - & - \\
\hline Farm 6 & Tie & Holstein-Friesian & Village & $14-18$ & - & - & - & - \\
\hline Farm 7 & Free & Holstein-Friesian & Village & $23-26$ & - & - & - & - \\
\hline Farm 8 & Tie & Holstein-Friesian & Village & $29-33$ & - & + & - & + \\
\hline Farm 9 & Tie & Holstein-Friesian & Village & $16-19$ & - & - & - & - \\
\hline Farm 10 & Tie & Holstein-Friesian & Village & $16-20$ & - & + & + & + \\
\hline Farm 11 & Tie + Grazing & Simmental & Rural & $14-16$ & - & - & - & - \\
\hline Farm 12 & Tie & Holstein-Friesian & Rural & $27-33$ & - & + & - & - \\
\hline Farm 13 & Tie & Mixed & Rural & $16-18$ & - & - & - & - \\
\hline Farm 14 & Tie & Simmental & Town & $11-18$ & - & + & - & - \\
\hline Farm 15 & Tie & Simmental & Town & $13-15$ & - & - & - & - \\
\hline Farm 16 & Tie & Simmental & Town & $13-15$ & - & - & - & - \\
\hline Farm 17 & Free & Simmental & Village & $31-40$ & - & + & - & - \\
\hline Farm 18 & Tie & Simmental & Rural & $11-14$ & - & + & - & - \\
\hline Farm 19 & Free & Holstein-Friesian & Village & $32-37$ & - & + & - & - \\
\hline Farm 20 & Tie & Simmental & Rural & 9-11 & - & + & - & - \\
\hline Total (\%) & & & & $9-40$ & $0 / 20(0 \%)$ & $10 / 20(50 \%)$ & $1 / 20(5 \%)$ & $4 / 20(20 \%)$ \\
\hline
\end{tabular}




\section{Environmental samples}

Environmental samples were collected from every farm during the meteorological autumn, winter, spring and summer. Manure, silage/hay, water from drinking bowls and soil samples from around the barn were collected in sterile 10-50 mL tubes (Sarstedt, Germany). Samples from other domestic animals present on the farm were collected with sterile swabs (Deltalab, Spain). Barn flies (Stomoxys calcitrans) and Barn swallow droppings (Hirundo rustica) were sampled only once during the summer. Barn flies were captured alive with hands, using clean latex gloves (Shield, UK) and stored in $10 \mathrm{~mL}$ sterile tubes (Deltalab, Spain). Barn swallow droppings were collected from surfaces under the nests within the barn using sterile swabs (Deltalab, Spain).

\section{Detection of Clostridium difficile}

All pooled fecal samples were used for molecular detection of $C$. difficile $16 \mathrm{~S}$ rDNA gene. Samples were processed within 2 days after collection. For total DNA isolation, SmartHelix ${ }^{\mathrm{TM}}$ First DNAid kit (IFB, Slovenia) was used as described previously [27]. Clostridium difficile $16 \mathrm{~S}$ rDNA gene was detected using an improved quantitative PCR (qPCR) that has the lowest detection (7.72 CD cells/g feces) and quantification limit (77.2 CD cells/g feces) published to date [27]. Calf fecal samples were analyzed individually when pooled fecal samples tested positive on qPCR.

Pooled fecal samples from cows and individual calf fecal samples, which were positive for $C$. difficile $16 \mathrm{~S}$ rDNA gene, were then cultured for $C$. difficile [7]. Samples were inoculated into cyloserine-cefoxitin fructose enrichment broth (Oxoid, UK) supplemented with $0.1 \%$ sodium taurocholate (Sigma, Aldrich) and cultured for 1 week in anaerobic conditions. Thereafter, $1 \mathrm{~mL}$ of inoculated broth from each sample and $1 \mathrm{~mL}$ of ethanol were mixed and left for $0.5 \mathrm{~h}$ at $20-25{ }^{\circ} \mathrm{C}$. Samples were later inoculated onto standard selective medium enriched with cycloserine and cefoxitin (C. difficile agar base and C. difficile selective supplement; Oxoid, UK) and left to incubate for $48 \mathrm{~h}$ anaerobically at $37{ }^{\circ} \mathrm{C}$. Preliminary identification of isolates was based on typical odor and morphologic criteria. One gram per sample, a swab or one $\mathrm{mL}$ of water sediment was used for culture. Environmental samples were cultured as described above.

\section{Molecular characterization of Clostridium difficile}

Clostridium difficile isolates recovered from fecal and environmental samples were characterized by PCRribotyping and toxinotyping. PCR-ribotyping was performed with primers for intergenomic region 16S-23S [28]. Amplification with PCR and electrophoresis of the PCR products on $3 \%$ agarose gel were done according to Janezic et al. [29]. PCR ribotypes were named using standard Cardiff/Leeds nomenclature (3-digit code). If reference strains were unavailable, the PCR ribotype was named using keys designated by internal nomenclature. Toxinotyping was performed using subsequent restriction PCR fragments for A3 (part of $C$. difficile toxin gene $\mathrm{A}, \mathrm{tcd} \mathrm{A}$ ) and $\mathrm{B} 1$ (part of $C$. difficile toxin gene $\mathrm{B}, \mathrm{tcdB}$ ) [30], while the gene for the binary toxin was detected using the protocol described by Stubbs et al. [31].

\section{Parasite burden on farms}

Parasitological evaluations of pooled fecal samples from cows and calves were performed every month during the sampling period using standard flotation and sedimentation techniques [32].

\section{Data collection and statistical analysis}

Information regarding feeding regimens, diseases, and treatments were obtained from farmers, farm veterinary services, and the Central Husbandry Register. Heat index [33] was obtained from the nearest National Meteorological Service weather station (Ljubljana, Slovenia- $14^{\circ} 5^{\prime} \mathrm{E}$, $46^{\circ} 1^{\prime} \mathrm{N}$ ). A mean value for heat index was calculated over 7 days prior to each sampling day.

The outcome in this study was the presence of $C$. difficile (present, not present) in four subgroups: (1) cows, (2) calves aged 0-21 days (first group), (3) calves aged 22-56 days (second group) and (4) calves aged 57-180 days (third group). The following risk factors were considered for each subgroup: Intestinal parasites, dietary change (a change from conserved to fresh feed), heat index, breed (Holstein-Friesian and Simmental), antibiotic treatment, other treatment (non-antibiotic treatment prescribed by the veterinarian), gastrointestinal disease, mastitis, other diseases, and meteorological season (Tables 4 and 5). The absence of a risk factor was considered as a reference category for odds ratio; a reference category for the outcome "Breed" was Holstein-Friesian.

The analyses were performed at the farm level. First, the univariate assessment of the association between each risk factor and different outcomes was performed by means of logistic regression where farm was included as the random effect. The week of sampling was included in each model as a fixed effect to adjust for the possible confounding effect of time. The variable was treated as continuous and a possible non-linear association was modelled using restricted cubic splines, however none of the models showed a significant effect of the non-linear term as judged by the likelihood ratio test $(p>0.05)$; therefore, only results for the linear association are reported. $P$-values were adjusted with the BenjaminiHochberg method (P.bh) to control the false discovery rate. Significance level was set to 0.05 for the adjusted 
$p$ values. When estimating the association between heat index and the outcomes a non-linear relation was modeled using restricted cubic splines. None of the models showed a significant effect of the non-linear term as judged by the likelihood ratio test; therefore, only results for the linear association are reported.

Following the univariate assessment, multivariate models were built for each outcome. Backward selection with a Bayes Information Criterion (BIC) cutoff value set to two was used for variable exclusion in random effects logistic regression models. These results were also verified using penalized random effects logistic regression where the penalization coefficient was determined through BIC. The variables selected by the two approaches were very similar; therefore, only results for the backward selection are reported.

Statistical analysis was performed using $\mathrm{R}$ language for statistical computing ( $\mathrm{R}$ version 3.0.1) [34].

\section{Results}

\section{Clostridium difficile prevalence}

Between farm prevalence. Clostridium difficile was detected in fecal samples from all farms on at least one sampling day (100\%). Throughout the year farms were positive for C. difficile on an average of $39.8 \%$ of sampling dates (whether calves, cows or both). Clostridium difficile was identified on each sampling day on at least $3(15 \%)$ and no more than 14 farms (70\%).

\section{Cow prevalence}

Fifty-four $(54 / 540 ; 10 \%)$ pooled cow fecal samples were positive for $C$. difficile with qPCR, which ranged from 0-44.4\% per farm. Bacterial culture identified C. difficile from only one pooled cow fecal sample.

\section{Calf prevalence}

In calves $(n=2442) C$. difficile $16 \mathrm{~S}$ gene was detected in 182 pooled samples (182/511, 35.6\%), which ranged from 3.7-66.7\% per farm. Clostridium difficile was identified with qPCR in 243 individual calf samples (243/2442, 10\%). Bacterial culture yielded $102 \mathrm{C}$. difficile isolates from 101 calves (Table 2).

\section{Environmental samples}

Clostridium difficile was also isolated from 11 winter, 16 spring, 16 summer and 18 autumn environmental samples (Table 3). However, two samples (one from the summer and one from the autumn), which were confirmed positive for $C$. difficile, were later lost during further culture processing. From other domestic animals on sampled farms, only poultry was found positive for C. difficile. Stable flies from two farms were found positive for $C$. difficile; only one isolate was then successfully cultured. No C. difficile was isolated from fecal droppings from Barn swallows sampled during their peak breeding season.

\section{Molecular characterization}

Overall from 103 C. difficile strains 16 PCR-ribotypes and 4 toxinotypes were cultured from cows and calves. In cows, only a toxin negative PCR-ribotype 071 was cultured, which was also identified in calves from the same farm. The most predominant $C$. difficile strain in calves was PCR-ribotype 033 (toxinotype XIa; 75.5\%). PCRribotypes 071 , SLO 084 and SLO 116 were toxin negative, whereas ribotype 023 was toxinotype IV. All other ribotypes (001/072, 002, 003, 005, 012, 014/020, 018, 077, SLO 029, SLO 036, SLO 195 new) were toxinotype 0 (Table 2).

Sixty-two $C$. difficile strains grouped into 19 different PCR-ribotypes (one new) and 6 different toxinotypes (toxin negative, 0, IV, V, XIa and XIc-new) were identified in the environment (Table 3). The most predominant $C$. difficile types were SLO 060 and 033 (toxinotype XIa,c). Toxin negative PCR-ribotypes were SLO 057, SLO 116 and SLO 196, whereas PCR-ribotype 023 was toxinotype IV and PCR-ribotype 045 was toxinotype V. All other ribotypes (001/072, 002, 003, 012, 014/020, 018, 077, 081, SLO 025, SLO 036, SLO 053, SLO 063) were toxinotype 0.

PCR-ribotype 001/072 was found in manure, soil and silage, while PCR-ribotype 014/020 was recovered from manure, soil and water samples.

Two strains of $C$. difficile were recovered from an adult rooster (PCR-ribotype/toxinotype; 045/V and SLO 060/ $\mathrm{XIa}$ ) and one new strain was isolated from a two-weekold rooster (SLO 196/toxin negative). Stable flies were infected with $C$. difficile PCR-ribotype/toxinotype 033/ $\mathrm{XIc}$ (new toxinotype), which was also present in manure and soil samples.

\section{Parasite burden between farms}

Parasites identified in pooled fecal samples were: Strongylida (65\%), Paramphistomum cervi (30\%), Nematodirus sp. (55\%), Strongyloides (15\%), Eimeria sp. (100\%), Monezia sp. (40\%) and Fasciola hepatica (5\%).

\section{Univariate analysis of risk factors}

In cows (Table 4), the only risk factor associated with C. difficile prevalence after adjusting for time of sampling were dietary changes (OR 5.0; 95\% CI 2.0-12.1; $P=0.0004 ;$ P.bh $=0.007$ ).

In the first age group of calves (Table 5) risk factors increasing $C$. difficile prevalence were dietary changes (OR 5.08; 95\% CI 2.3-77.9; $P=0.004 ;$ P.bh = 0.04) and breeding Simmental cattle (OR 5.3; 95\% CI 1.9-14.7; $P=0.001 ;$ P.bh $=0.03$ ). 


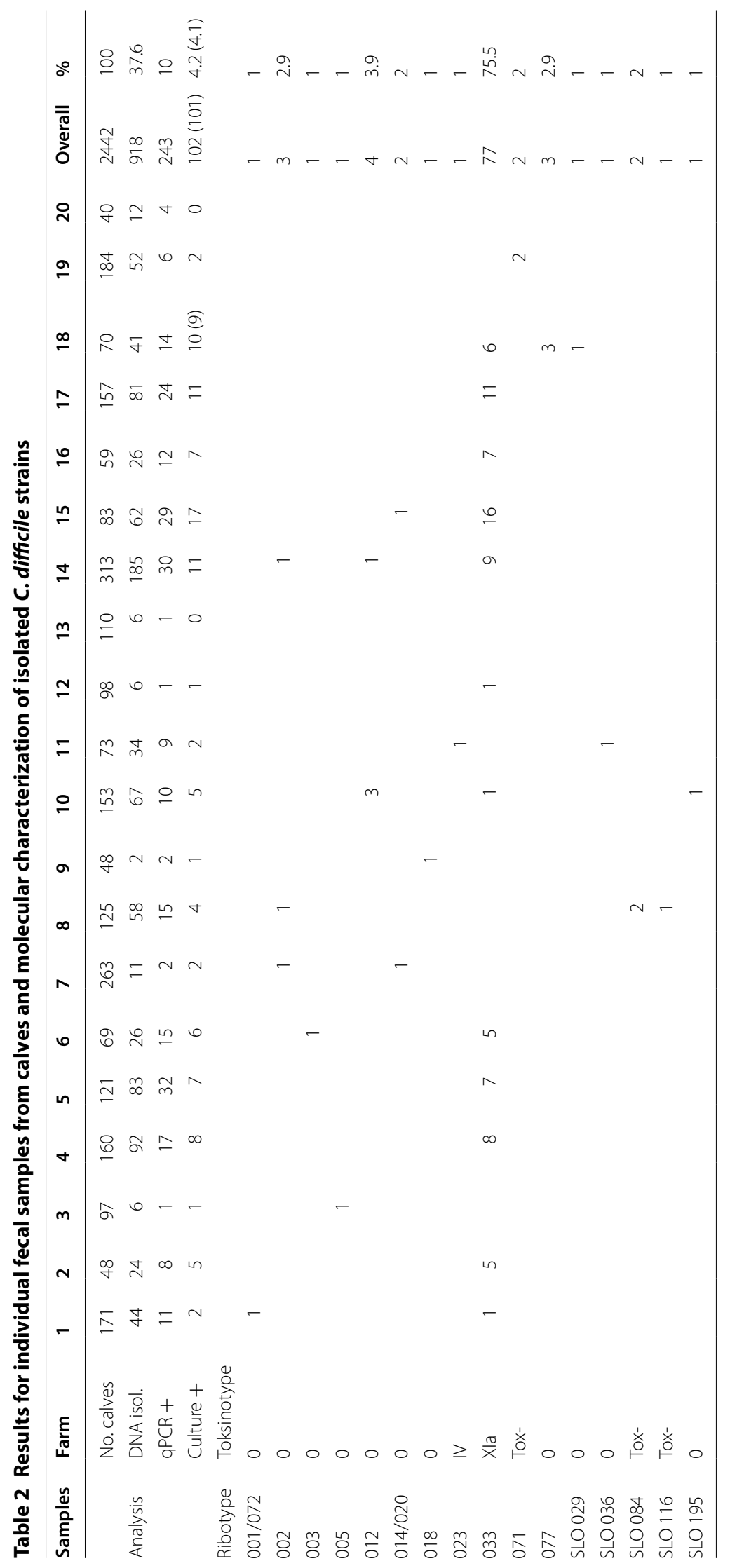


Table 3 Clostridium difficile isolates from environmental samples and their molecular characterization

\begin{tabular}{|c|c|c|c|c|c|c|c|}
\hline \multirow{2}{*}{$\begin{array}{l}\text { Environmental } \\
\text { samples }\end{array}$} & \multicolumn{5}{|c|}{ C. difficile culture results } & \multicolumn{2}{|c|}{ C. difficile strain characterization } \\
\hline & Winter & Spring & Summer & Autumn & All year & Ribotypes & Toxinotypes \\
\hline Manure & $4 / 20(20 \%)$ & $7 / 20(35 \%)$ & $5 / 20(25 \%)$ & $7 / 20(35 \%)$ & 23/80 (28.7\%) & $\begin{array}{l}\text { 001/072, 002, } \\
\text { 014/020, 023, 033, } \\
\text { 077, SLO 036, SLO } \\
\text { 053, SLO } 060\end{array}$ & 0, IV, Xla, XIC (new) \\
\hline Soil & $5 / 20(25 \%)$ & $8 / 20(40 \%)$ & $7 / 20(35 \%)$ & $8 / 20(40 \%)$ & 28/80 (35\%) & $\begin{array}{l}\text { 001/072, 012, } \\
\text { 014/020, 018, 023, } \\
\text { 033, 081, SLO 025, } \\
\text { SLO 057, SLO 060, } \\
\text { SLO } 063\end{array}$ & $\begin{array}{l}\text { 0, IV, Xla, XIc (new), } \\
\text { tox- }\end{array}$ \\
\hline Silage/hay & 0/20 (0\%) & $1 / 20(5 \%)$ & $0 / 20(0 \%)$ & $2 / 20(10 \%)$ & $3 / 80(3.75 \%)$ & $\begin{array}{l}001 / 072,003, \text { SLO } \\
116\end{array}$ & 0, tox- \\
\hline Water & $1 / 20(5 \%)$ & $0 / 20(0 \%)$ & $1 / 20(5 \%)$ & $1 / 20(5 \%)$ & $3 / 80(3.75 \%)$ & 014/020, SLO 036 & 0, Xla \\
\hline $\begin{array}{l}\text { Other animals on } \\
\text { farms }\end{array}$ & $\begin{array}{l}1 \text { (2 strains)/32 } \\
(3.1 \%) \text {-adult } \\
\text { rooster }\end{array}$ & $0 / 33(0 \%)$ & $\begin{array}{l}\text { 1/24 (4.2\%)-rooster } \\
2 \text { weeks }\end{array}$ & $0 / 26(0 \%)$ & $2 / 115(1.7 \%)$ & $\begin{array}{l}\text { 045, SLO 060, SLO } \\
196 \text { (new) }\end{array}$ & V, Xla, tox- \\
\hline $\begin{array}{l}\text { Barn swallows } \\
\text { (Hirundo rustica) }\end{array}$ & / & / & $0 / 20(0 \%)$ & / & $0 / 20(0 \%)$ & & \\
\hline $\begin{array}{l}\text { Stable flies (Sto- } \\
\text { moxys calcitrans) }\end{array}$ & / & / & $2 / 20(10 \%)$ & / & $2 / 20(10 \%)$ & 033 & XIc (new) \\
\hline Total & $11(12) / 112(9.8 \%)$ & 16/113 (14.2\%) & 16/144 (11.1\%) & 18/106 (17\%) & $61 / 475(12.8 \%)$ & & \\
\hline
\end{tabular}

Table 4 Risk factors associated with the prevalence of $C$. difficile in cows and third age group of calves (57-180 days)

\begin{tabular}{|c|c|c|c|c|c|c|c|c|c|c|}
\hline \multirow{2}{*}{$\begin{array}{l}\text { Age group } \\
\text { Risk factors }\end{array}$} & \multicolumn{5}{|l|}{ Cows } & \multicolumn{5}{|c|}{ Calves $57-180$ days } \\
\hline & Odds ratio & $\mathrm{Cl}$, low & $\mathrm{Cl}$, up & $P$ value & P.bh & Odds ratio & $\mathrm{Cl}$, low & $\mathrm{Cl}$, up & $P$ value & P.bh \\
\hline Intestinal parasites cows & 0.67 & 0.27 & 1.67 & 0.397 & 0.685 & 1.11 & 0.45 & 2.73 & 0.805 & 0.899 \\
\hline Intestinal parasites calves & 0.97 & 0.47 & 1.98 & 0.937 & 0.976 & 1.12 & 0.53 & 2.37 & 0.760 & 0.899 \\
\hline Dietary change & 5.00 & 2.06 & 12.11 & 0.001 & 0.007 & 2.84 & 1.10 & 7.35 & 0.030 & 0.289 \\
\hline Heat index & 0.95 & 0.91 & 0.99 & 0.046 & 0.323 & 0.98 & 0.93 & 1.02 & 0.423 & 0.899 \\
\hline Breed & 1.80 & 0.58 & 5.57 & 0.304 & 0.685 & 2.82 & 1.23 & 6.47 & 0.014 & 0.268 \\
\hline Antibiotic treatment: cows & 1.72 & 0.86 & 3.43 & 0.118 & 0.323 & 1.26 & 0.59 & 2.69 & 0.545 & 0.899 \\
\hline Other treatment: cows & 1.85 & 0.91 & 3.74 & 0.087 & 0.323 & 1.16 & 0.51 & 2.60 & 0.715 & 0.899 \\
\hline Gl diseases: cows & 1.60 & 0.54 & 4.68 & 0.390 & 0.685 & 0.86 & 0.18 & 4.18 & 0.862 & 0.909 \\
\hline Mastitis & 1.30 & 0.58 & 2.88 & 0.513 & 0.750 & 1.16 & 0.48 & 2.78 & 0.736 & 0.899 \\
\hline Other diseases: cow & 3.38 & 0.72 & 15.73 & 0.119 & 0.323 & 0.00 & 0.00 & $\infty$ & 1.000 & 1.000 \\
\hline Antibiotic treatment: calves & 0.64 & 0.19 & 2.11 & 0.468 & 0.741 & 0.56 & 0.12 & 2.64 & 0.472 & 0.899 \\
\hline Other treatment: calves & 1.18 & 0.46 & 3.02 & 0.723 & 0.858 & 1.26 & 0.44 & 3.61 & 0.664 & 0.899 \\
\hline Gl diseases: calves & 0.00 & 0.00 & $\infty$ & 0.976 & 0.976 & 1.55 & 0.16 & 14.32 & 0.696 & 0.899 \\
\hline Other diseases: calves & 1.40 & 0.42 & 4.66 & 0.5764 & 0.782 & 1.33 & 0.35 & 5.06 & 0.669 & 0.899 \\
\hline Meteorological season-winter vs & & & & 0.060 & 0.323 & & & & 0.230 & 0.899 \\
\hline Spring & 1.20 & 0.48 & 3.00 & 0.693 & 0.858 & 1.52 & 0.57 & 4.01 & 0.395 & 0.899 \\
\hline Autumn & 0.55 & 0.14 & 2.10 & 0.391 & 0.685 & 0.58 & 0.14 & 2.36 & 0.451 & 0.899 \\
\hline Summer & 0.32 & 0.09 & 1.14 & 0.079 & 0.323 & 0.64 & 0.17 & 2.34 & 0.503 & 0.899 \\
\hline
\end{tabular}

Cl: 95\% confidential intervals.

P.bh: $P$ values adjusted with Benjamimi and Hochberg method. 
Table 5 Risk factors associated with the prevalence of C. difficile in calves-First (0-21 days) and second (22-56 days) age group

\begin{tabular}{|c|c|c|c|c|c|c|c|c|c|c|}
\hline \multirow{2}{*}{$\begin{array}{l}\text { Age group } \\
\text { Risk factors }\end{array}$} & \multicolumn{5}{|c|}{ Calves 0-21 days } & \multicolumn{5}{|c|}{ Calves 2-56 days } \\
\hline & Odds ratio & $\mathrm{Cl}$, low & $\mathrm{Cl}$, up & $P$ value & P.bh & Odds ratio & $\mathrm{Cl}$, low & $\mathrm{Cl}$, up & $P$ value & P.bh \\
\hline Intestinal parasites cows & 0.61 & 0.27 & 1.37 & 0.237 & 0.612 & 1.18 & 0.50 & 2.82 & 0.694 & 0.879 \\
\hline Intestinal parasites calves & 0.71 & 0.36 & 1.38 & 0.322 & 0.612 & 1.71 & 0.83 & 3.52 & 0.143 & 0.543 \\
\hline Dietary change & 13.27 & 2.26 & 77.93 & 0.004 & 0.039 & 1.19 & 0.31 & 4.52 & 0.793 & 0.941 \\
\hline Heat index & 1.00 & 0.96 & 1.04 & 0.866 & 0.951 & 1.00 & 0.96 & 1.05 & 0.668 & 0.879 \\
\hline Breed & 5.27 & 1.88 & 14.76 & 0.002 & 0.029 & 2.77 & 0.87 & 8.83 & 0.083 & 0.395 \\
\hline Antibiotic treatment: cows & 1.94 & 0.54 & 1.02 & 0.929 & 0.951 & 6.62 & 1.45 & 3.10 & 0.003 & 0.032 \\
\hline Other treatment: cows & 1.56 & 0.79 & 3.06 & 0.197 & 0.612 & 2.60 & 1.21 & 5.59 & 0.014 & 0.088 \\
\hline Gl diseases: cows & 2.69 & 0.34 & 0.96 & 0.951 & 0.951 & 1.38 & 0.39 & 4.82 & 0.608 & 0.879 \\
\hline Mastitis & 1.09 & 0.51 & 2.29 & 0.819 & 0.951 & 3.48 & 1.52 & 7.94 & 0.003 & 0.032 \\
\hline Other diseases: cow & 7.57 & 0.38 & 1.70 & 0.486 & 0.768 & 1.16 & 0.20 & 6.69 & 0.865 & 0.966 \\
\hline Antibiotic treatment: calves & 1.03 & 0.41 & 2.54 & 0.943 & 0.951 & 1.94 & 0.72 & 5.20 & 0.188 & 0.556 \\
\hline Other treatment: calves & 1.14 & 0.50 & 2.57 & 0.745 & 0.951 & 3.98 & 0.59 & 1.54 & 0.371 & 0.767 \\
\hline Gl diseases: calves & 1.76 & 0.38 & 8.08 & 0.463 & 0.768 & 0.00 & 0.00 & $\infty$ & 0.988 & 0.994 \\
\hline Other diseases: calves & 0.54 & 0.16 & 1.76 & 0.311 & 0.612 & 1.00 & 0.31 & 3.22 & 0.994 & 0.994 \\
\hline Meteorological season-winter vs & & & & 0.089 & 0.423 & & & & 0.383 & 0.767 \\
\hline Spring & 2.02 & 0.84 & 4.84 & 0.114 & 0.431 & 0.71 & 0.27 & 1.87 & 0.498 & 0.859 \\
\hline Autumn & 1.66 & 0.63 & 4.36 & 0.300 & 0.612 & 0.61 & 0.20 & 1.90 & 0.404 & 0.767 \\
\hline Summer & 3.35 & 1.22 & 9.18 & 0.018 & 0.116 & 1.27 & 0.40 & 4.02 & 0.682 & 0.879 \\
\hline
\end{tabular}

Cl: 95\% confidential intervals, P.bh: $P$ values adjusted with Benjamimi and Hochberg method.

Antibiotic treatment (OR 3.1; 95\% CI 1.4-6.6; $P=0.003$; P.bh $=0.03$ ) and mastitis (OR 3.4; 95\% CI 1.57.9; $P=0.003$; P.bh $=0.03)$ increased $C$. difficile prevalence in the second age group of calves (Table 5).

No risk factors associated with the $C$. difficile prevalence in the third age group of calves (Table 4) were identified after adjusting for time of sampling.

\section{Multivariate analysis of risk factors}

In cows, dietary changes were associated with the prevalence of $C$. difficile (OR 5.8; 95\% CI 2.4-14.4; $P=0.0001$ ). Similarly, in the first age group of calves, dietary changes were associated with the prevalence of $C$. difficile (OR 17.2; 95\% CI 2.8-106.0; $P=0.002)$. Mastitis was identified as a risk factor in the second group of calves (OR 1.6; 95\% CI 0.7-3.4; $P=0.001$ ). Dietary changes also increased the prevalence of $C$. difficile in the third group of calves (OR 2.8; 95\% CI 1.0-7.4; $P=0.03$ ) (Table 6).

Parasites were not shown to be a risk factor, which would directly influence the prevalence of $C$. difficile. However, they were identified to influence risk factors, which increased the prevalence of $C$. difficile in the multivariate analysis (Table 6).

\section{Discussion}

This study investigated the role of family farming on the ecology and epidemiology of $C$. difficile, which could be associated with the community-acquired CDI [7-10]. Dietary changes were the most prominent risk factor associated with the prevalence of $C$. difficile. The Clostridium difficile ribotypes identified in this study suggest that family dairy farming in Europe is an unlikely source for CDI.

Community-acquired CDI is a significant medical problem in human medicine. Animal contact is suggested as a potential risk factor for the development of community-acquired CDI $[35,36]$, because of the high prevalence of $C$. difficile in pigs, cattle and poultry on large scale intensive farms [8, 11, 20, 21, 35-38]. Intensive farming management subjects animals to a substantial stress, which increases the likelihood for pathogen transmission [39]. Human animal interaction in large intensive farms is reduced to a minimum and animals in intensive production have limited contact with other animal species that could harbor or transmit pathogenic organisms. Most likely transmission of a pathogen from large intensive farms, therefore, is through a food chain. Farming management on smaller family farms is less stressful for animals and has smaller negative impact on the environment [40]. Such farms are also more interlinked within the community, and a direct or indirect transmission of pathogens between animals, and animals and humans, is possible, including food chain transmission [41]. 
Table 6 Multivariate analysis

\begin{tabular}{|c|c|c|c|c|c|c|}
\hline Outcome & & Regression coefficient & Odds ratio & $\mathrm{Cl}$, low & $\mathrm{Cl}$, up & $P$ value \\
\hline \multirow[t]{3}{*}{ Cows } & Intercept & -2.490 & & & & $<0.0001$ \\
\hline & Dietary change & 1.772 & 5.881 & 2.401 & 14.405 & 0.0001 \\
\hline & Intestinal parasites cows & -0.448 & 0.639 & 0.248 & 1.644 & 0.3531 \\
\hline Calves & Intercept & -0.437 & & & & 0.2357 \\
\hline \multirow[t]{2}{*}{ First age group } & Dietary change & 2.849 & 17.263 & 2.810 & 106.027 & 0.0021 \\
\hline & Intestinal parasites calves & -0.430 & 0.650 & 0.330 & 1.282 & 0.2145 \\
\hline Calves & Intercept & -1.909 & & & & $<0.0001$ \\
\hline \multirow[t]{2}{*}{ Second age group } & Mastitis & 1.407 & 4.083 & 1.729 & 9.639 & 0.0013 \\
\hline & Intestinal parasites calves & 0.488 & 1.629 & 0.773 & 3.432 & 0.1991 \\
\hline Calves & Intercept & -2.576 & & & & $<0.0001$ \\
\hline \multirow[t]{2}{*}{ Third age group } & Dietary change & 1.037 & 2.819 & 1.073 & 7.407 & 0.0354 \\
\hline & Intestinal parasites calves & 0.061 & 1.062 & 0.502 & 2.246 & 0.8739 \\
\hline
\end{tabular}

Calves first age group: 0-21 days; Calves second age group: 22-56 days; Calves third age group: 57-180 days.

Several longitudinal studies investigated the prevalence of $C$. difficile in different domestic animal species during different ages or production stages, spanning over a period of 1 month to a year [11, 21-23, 38, 42]. The farm prevalence in this study varied from 3.7 to $74.1 \%$; all farms were positive on at least one sampling day. Other studies also suggest transient shedding patters of $C$. difficile [11, 42]. A prevalence of $10 \%$ in cows was found in this study. This is more than in large intensive dairy farms where prevalence of 0.95 [10], 1.5 [43], 2.4 [44] and 4.5\% [45] were reported based on a single sampling interval. As expected, calves (35.7\%) had much higher C. difficile prevalence than cows in this study. Studies reporting prevalence of $C$. difficile in calves reported prevalence from 6 to $22 \%$ [10, 22-24, 43, 46, 47], and even $56 \%$ in calves less than 7 days old [36]. The use of qPCR as a screening method made $C$. difficile detection more sensitive [27], which most likely accounted for the higher $C$. difficile prevalence in this study compared to other studies. Several sampling stages over a prolonged period are also more likely to identify bacteria in the investigated population.

Clostridium difficile bacterial culture results in this study, however, are more in line with previously published data. Considering the results of a bacterial culture, the prevalence in cows and calves would be $0.2 \%(1 / 540$ pooled samples) and 4.1\% (101/2442 individual samples), respectively. Results based on the bacterial culture indicated lower $C$. difficile prevalence than that reported in studies investigating animals on large intensive farms $[8$, $10,22,23,37,48,49]$.

Sixteen PCR-ribotypes were identified from cattle samples and 19 from environmental samples. Eleven PCR-ribotypes were found in both, cattle and the environment. Two new PCR-ribotype strains (SLO 195, SLO
196) and a new toxinotype (XIc) were identified. PCRribotype 033 was the most frequently determined PCRribotype in this study, which has often been reported in calves and humans, but has not been linked to the community-acquired CDI $[7,10,23,43,46,50,51]$. Other PCR-ribotypes found were associated with CDI including ribotypes 001/072, 002, 012 and 014/020 [10, 29, 52, 53]. PCR ribotype 014/020 was previously isolated from meat products in Canada [54, 55]. PCR ribotype 078, which is closely associated with the rising incidence of community-acquired CDI $[5,10,52]$ and has been identified on large cattle farms $[8,23,48-50,56]$, has not been detected in this study. It has been suggested that the exposure to less toxigenic strains of $C$. difficile such as PCR-ribotype 033 may help protect people or animals against more toxigenic strains and decrease the incidence of community-acquired CDI $[57,58]$.

The most important risk factor influencing the prevalence of $C$. difficile in this study were dietary changes. A similar result was found in horses $[5,13,18]$ but not in other farm animals. Breeding/rearing Simmental cattle increased the risk for $C$. difficile shedding in the first age group of calves. They were at least five times more likely to shed $C$. difficile than Holstein-Friesian calves in the same age group. We were not able to identify the reason for this prevalence difference. Most $C$. difficile ribotypes identified in Simmental cattle were not regarded as dangerous for $\mathrm{CDI}$, which could competitively reduce the presence of more dangerous strains of $C$. difficile in the environment and potentially make them a safer breed of cattle $[57,58]$.

The prevalence of $C$. difficile in cows was not associated with the presence of diseases, nor with antibiotic and non-antibiotic treatment, which is in agreement with previous studies $[24,48,49]$. Clostridium difficile 
prevalence in the second age group of calves, however, was sensitive to the antibiotic treatment in cows, as well as to the presence of mastitis on the farm. Possible reason for this finding is the shift in rumen microbiota in calves after the age of 3 weeks [26]. Another reason is a greater likelihood of the second age group of calves to be fed waste milk [59].

Gastrointestinal diseases were not linked to increased prevalence of $C$. difficile in cows or calves. Most animals included in the gastrointestinal disease group in this study had diarrhea. Diarrhea was $[19,37]$ or was not $[24$, 60-62] identified as a risk factor in other studies. Intestinal parasites have contributed to the potency of risk factors identified in the multivariate analysis. Interaction between intestinal pathogens is often the culprit for the development of gastrointestinal diseases in individuals and the population $[63,64]$ and warrants detailed investigation in the population.

Environmental temperatures and humidity are considered significant stress factors for production animals, which can influence the presence of $C$. difficile in feces [65-68]. Rodriguez-Palacios et al. [55] reported a positive association between $C$. difficile isolation in meat products in Canada with the months of January and February. In calves aged less than 1 month it was more likely to isolate $C$. difficile from their feces during the months of May, June and July when compared to August [24]. In the present study meteorological season and heat index did not influence the prevalence of $C$. difficile.

It is always important to be familiar with factors, which may influence the epidemiology of the disease and the biology of the etiological factor. This study provides significant information with regards to the epidemiology of $C$. difficile on the most prominent farming model in Europe. The results of this study indicate that it is unlikely that mid-size family dairy farms in Europe harbor highly pathogenic $C$. difficile strains, which are found to cause disease in animals and humans. The predominant presence of the benign $C$. difficile PCR-ribotype 033 may even have a protective rather than pathologic role in the pathogenesis of the disease.

\section{Abbreviations}

BVD: bovine viral diarrhea; CDI: Clostridium difficile infection; IBR: infectious bovine rhinotracheitis; MAP: Mycobacterium avium subsp. paratuberculosis.

\section{Competing interests}

The authors declare that they have no competing interests.

\footnotetext{
Author details

${ }^{1}$ Veterinary faculty, University of Ljubljana, cesta v Mestni log 47, 1115 Ljubljana, Slovenia. ${ }^{2}$ Institute for biostatistics and Medical informatics, University of Ljubljana, Vrazov trg 2, 1104 Ljubljana, Slovenia. ${ }^{3}$ Vodnikova cesta 243, 1000 Ljubljana, Slovenia. ${ }^{4}$ Vinharje 6, 4223 Poljane nad Skofjo Loko, Slovenia. ${ }^{5}$ National Laboratory for Health, Environment and Food, Prvomajska ulica 1, 2000 Maribor, Slovenia. ${ }^{6}$ Faculty of Medicine, University of Maribor,
}

Taborska ulica 8, 2000 Maribor, Slovenia. ${ }^{7}$ Centre of Excellence for Integrated Approaches in Chemistry and Biology of Proteins, Jamova cesta 39, 1000 Ljubljana, Slovenia.

\section{Authors' contributions}

The study was designed by MV, PB, MO and MR. The sampling protocol and population size were set by RB, MV and PB. The farms were selected by FB and PB. Sampling was carried out by PB, MV, FB and OF. Molecular detection and culture were performed by PB. Molecular characterization of isolates was performed by MR. Statistical analysis and interpretations were performed by $\mathrm{RB}$ and MV. Parasitological examination of samples was carried out by AVR. MV and $\mathrm{PB}$ wrote the manuscript. MO, RB and MR critically revised the manuscript. All authors read and approved the final manuscript.

\section{Acknowledgements}

This work was financed with the support of Slovenian National Research Agency (Grant nos. J4-2236, J3-4298 and P4-0092, and grant for young researchers_-P. Bandelj). The authors thank Milojka Setina, Alenka Magdalena Usenik, Dr Katarina Logar, Dr Tina Pirs, Dr Darja Kusar, mag. Maja Kavalic, Dr Marko Cotman, Dr Irena Zdovc, Dr Peter Hostnik and all participating farmers for their collaboration and assistance.

Received: 22 May 2015 Accepted: 25 January 2016

Published online: 12 March 2016

\section{References}

1. CDCP (Center for Disease Control and Prevention) (2005) Severe Clostrid ium difficile-associated disease in populations previously at low risk-four states, 2005. MMWR Morb Mortal Wkly Rep 54:1201-1205

2. Paltansing S, van den Berg RJ, Guseinova RA, Visser CE, van der Vorm ER, Kuijper EJ (2007) Characteristics and incidence of Clostridium difficileassociated disease in The Netherlands, 2005. Clin Microbiol Infect 13:1058-1064

3. Wilcox MH, Mooney L, Bendall R, Settle CD, Fawley WN (2008) A casecontrol study of community-associated Clostridium difficile infection. J Antimicrob Chemother 62:388-396

4. Limbago BM, Long CM, Thompson AD, Killgore GE, Hannett GE, Havill NL, Mickelson S, Lathrop S, Jones TF, Park MM, Harriman KH, Gould LH, McDonald LC, Angulo FJ (2009) Clostridium difficile strains from community-associated infections. J Clin Microbiol 47:3004-3007

5. Keessen EC, van den Berkt AJ, Haasjes NH, Hermanus C, Kuijper EJ, Lipman LJA (2011) The relation between farm specific factors and prevalence of Clostridium difficile in slaughter pigs. Vet Microbiol 154:130-134

6. Juneau C, Mendias EN, Wagal N, Loeffelholz M, Savidge T, Croisant S, Dann S (2013) Community-acquired Clostridium difficile infection: awareness and clinical implications. J Nurse Pract 9:1-6

7. Avbersek J, Janezic S, Pate M, Rupnik M, Zidaric V, Logar K, Vengust M, Zemljic M, Pirs T, Ocepek M (2009) Diversity of Clostridium difficile in pigs and other animals in Slovenia. Anaerobe 15:252-255

8. Costa MC, Stämpfli HR, Arroyo LG, Pearl DL, Weese JS (2011) Epidemiology of Clostridium difficile on a veal farm: prevalence, molecular characterization and tetracycline resistance. Vet Microbiol 152:379-384

9. Burt SA, Siemeling L, Kuijper EJ, Lipman LJA (2012) Vermin on pig farms are vectors for Clostridium difficile PCR ribotypes 078 and 045. Vet Microbiol 160:256-258

10. Koene MGJ, Mevius D, Wagenaar JA, Harmanus C, Hensgens MPM, Meetsma AM, Putirulan FF, Van Bergen MAP, Kuijper EJ (2012) Clostridium difficile in Dutch animals: their presence, characteristics and similarities with human isolates. Clin Microbiol Infect 18:778-784

11. Weese JS, Wakeford T, Reid-Smith R, Rousseau J, Friendship R (2010) Longitudinal investigation of Clostridium difficile shedding in piglets. Anaerobe 16:501-504

12. Frazier KS, Herron AJ, Hines ME II, Gaskin JM, Altman NH (1993) Diagnosis of enteritis and enterotoxemia due to Clostridium difficile in captive ostriches (Struthio camelus). J Vet Diagn Invest 5:623-625

13. Båverud V, Gustafsson A, Franklin A, Lindholm A, Gunnarsson A (1997) Clostridium difficile associated with acute colitis in mature horses treated with antibiotics. Equine Vet J 29:279-284 
14. Gustafsson A, Båverud V, Gunnarsson A, Rantzien MH, Lindholm A, Franklin A (1997) The association of erythromycin ethylsuccinate with acute colitis in horses in Sweden. Equine Vet J 29:314-318

15. Båverud V, Franklin A, Gunnarsson A, Gustafsson A, Hellander-Edman A (1998) Clostridium difficile associated with acute colitis in mares when their foals are treated with erythromycin and rifampicin for Rhodococcus equi pneumonia. Equine Vet J 30:482-488

16. Songer JG, Post KW, Larson DJ, Jost BH, Glock RD (2000) Infection of neonatal swine with Clostridium difficile. Swine Health Prod 8:185-189

17. Båverud V, Gustafsson A, Franklin A, Aspán A, Gunnarsson A (2003) Clostridium difficile: prevalence in horses and enviroment, and antimicrobial susceptibility. Equine Vet J 35:465-471

18. Gustafsson A, Båverud V, Gunnarsson A, Pringle J, Franklin A (2004) Study of faecal shedding of Clostridium difficile in horses treated with penicillin. Equine Vet J 36:180-182

19. Clooten J, Kruth S, Arroyo L, Weese JS (2008) Prevalence and risk factors for Clostridium difficile colonization in dogs and cats hospitalized in an intensive care unit. Vet Microbiol 129:209-214

20. Hopman NEM, Keessen EC, Harmanus C, Sanders IMJG, van Leengoed LAMG, Kuijper EJ, Lipman LJA (2011) Acquisition of Clostridium difficile by piglets. Vet Microbiol 149:186-192

21. Hawken P, Weese JS, Friendship R, Warriner K (2013) Longitudinal study of Clostridium difficile and Methicillin-resistant Staphylococcus aureus associated with pigs from weaning through to the end of processing. J Food Prot 76:624-630

22. Houser BA, Soehnlen MK, Wolfgang DR, Lysczek HR, Burns CM, Jayarao BM (2012) Prevalence of Clostridium difficile toxin genes in the feces of veal calves and incidence of ground veal contamination. Foodborne Pathog Dis 9:32-36

23. Zidaric V, Pardon B, dos Vultos T, Deprez P, Brouwer MSM, Roberts AP, Henriques $A O$, Rupnik M (2012) Different antibiotic resistance and sporulation properties within multiclonal Clostridium difficile PCR ribotypes 078, 126, and 033 in a single calf farm. Appl Environ Microbiol 78:8515-8522

24. Rodriguez-Palacios A, Staempfli HR, Duffield T, Peregrine AS, TrotzWilliams LA, Arroyo LG, Brazier JS, Weese JS (2006) Clostridium difficile PCR ribotypes in calves, Canada. Emerg Infect Dis 12:1730-1736

25. European Commission. Agriculture and rural development - Family farming (2015) http://ec.europa.eu/agriculture/family-farming/index_en.htm. Accessed 20 May 2015

26. Drackley JK (2008) Calf nutrition from birth to breeding. Vet Clin North Am Food Anim Pract 24:55-86

27. Bandelj P, Logar K, Usenik AM, Vengust M, Ocepek M (2013) An improved qPCR protocol for rapid detection and quantification of Clostridium difficile in cattle feces. FEMS Microbiol Lett 341:115-121

28. Bidet P, Barbut F, Lalande V, Burghoffer B, Petit JC (1999) Development of a new PCR-ribotyping method for Clostridium difficile based on ribosomal RNA gene sequencing. FEMS Microbiol Lett 175:261-266

29. Janezic S, Ocepek M, Zidaric V, Rupnik M (2012) Clostridium difficile genotypes other than ribotype 078 that are prevalent among human, animal and environmental isolates. BMC Microbiol 12:48

30. Rupnik M, Avesani V, Janc M, von Eichel-Streiber C, Delmée M (1998) A novel toxinotyping scheme and correlation of toxinotypes with serogroups of Clostridium difficile isolates. J Clin Microbiol 36:2240-2247

31. Stubbs S, Rupnik M, Gibert M, Brazier J, Duerden B, Popoff M (2000) Production of actin-specific ADP-ribosyltransferase (binary toxin) by strains of Clostridium difficile. FEMS Microbiol Lett 186:307-312

32. Thienpont D, Rochette F, Vanparijs OFJ (1979) Diagnosing helminthiasis through coprological examination. Janssen Research Foundation, Beerse, pp 31-34

33. Steadman RG (1979) The assessment of sultriness. Part I: a temperaturehumidity index based on human physiology and clothing science. J Appl Meteor 18:861-873

34. R Core Team. R: A language and environment for statistical computing (2013) R Foundation for Statistical Computing, Vienna, Austria. http:// www.R-project.org/. Accessed 20 May 2015

35. Simango C, Mwakurudza S (2008) Clostridium difficile in broiler chickens sold at market places in Zimbabwe and their antimicrobial susceptibility. Int J Food Microbiol 124:268-270

36. Knight DR, Thean S, Putsathit P, Fenwick S, Riley TV (2013) Cross-sectional study reveals high prevalence of Clostridium difficile non-PCR ribotype
078 strains in Australian veal calves at slaughter. Appl Environ Microbiol 79:2630-2635

37. Hammitt MC, Bueschel DM, Keel MK, Glock RD, Cuneo P, DeYoung DW Reggiardo C, Trinh HT, Songer JG (2008) A possible role for Clostridium difficile in the etiology of calf enteritis. Vet Microbiol 127:343-352

38. Zidaric V, Zemljic M, Janezic S, Kocuvan A, Rupnik M (2008) High diversity of Clostridium difficile genotypes isolated from a single poultry farm producing replacement laying hens. Anaerobe 14:325-327

39. CIWF (Compassion in world farming) (2013) Zoonotic diseases, human health and farm animal welfare. http://www.ciwf.org.uk/includes/documents/ cm_docs/2013/z/zoonoses_4page_report.pdf. Accessed 20 May 2015

40. Schmitzberger I, Wrbka Th, Steurer B, Aschenbrenner G, Peterseil J, Zechmeister HG (2005) How farming styles influence biodiversity maintenance in Austrian agricultural landscapes. Agric Ecosyst Environ 108:274-290

41. Swagemakers P, Wiskerke H, Van Der Ploeg JD (2009) Linking birds, fields and farmers. J Environ Manage 90(Suppl 2):S185-S192

42. Schoster A, Staempfli HR, Arroyo LG, Reid-Smith RJ, Janecko N, Shewen PE, Weese JS (2012) Longitudinal study of Clostridium difficile and antimicrobial susceptibility of Escherichia coli in healthy horses in a community setting. Vet Microbiol 159:364-370

43. Romano V, Albanese F, Dumontet S, Krovacek K, Petrini O, Pasquale (2012) Prevalence and genotypic characterization of Clostridium difficile from ruminants in Switzerland. Zoonoses Public Health 59:545-548

44. Thitaram SN, Frank JF, Lyon SA, Siragusa GR, Bailey JS, Lombard JE, Haley CA, Wagner BA, Dargatz DA, Fedorka-Cray PJ (2011) Clostridium difficile from healthy food animals: optimized isolation and prevalence. J Food Prot 74:130-133

45. Indra A, Lassnig H, Baliko N, Much P, Fiedler A, Huhulescu S, Allerberger F (2009) Clostridium difficile: a new zoonotic agent? Wien Klin Wochenschr 121:91-95

46. Pirs T, Ocepek M, Rupnik M (2008) Isolation of Clostridium difficile from food animals in Slovenia. J Med Microbiol 57:790-792

47. Rodriguez C, Taminiau B, Van Broeck J, Avesani V, Delmée M, Daube G (2012) Clostridium difficile in young farm animals and slaughter animals in Belgium. Anaerobe 18:621-625

48. Rodriguez-Palacios A, Pickworth C, Loerch S, LeJeune JT (2011) Transient fecal shedding and limited animal-to-animal transmission of Clostridium difficile by naturally infected finishing feedlot cattle. Appl Environ Microbiol 77:3391-3397

49. Costa MC, Reid-Smith R, Gow S, Hannon SJ, Booker C, Rousseau J, Benedict KM, Morley PS, Weese JS (2012) Prevalence and molecular characterization of Clostridium difficile isolated from feedlot beef cattle upon arrival and mid-feeding period. BMC Vet Res 8:38

50. Keel K, Brazier JS, Post KW, Weese JS, Songer JG (2007) Prevalence of PCR Ribotypes among Clostridium difficile isolates from pigs, calves, and other species. J Clin Microbiol 45:1963-1964

51. Janezic S, Zidaric V, Pardon B, Indra A, Kokotovic B, Blanco JL, Seyboldt C, Diaz CR, Poxton IR, Perreten V, Drigo I, Jiraskova A, Ocepek M, Weese JS, Songer JG, Wilcox MH, Rupnik M (2014) International Clostridium difficile animal strain collection and large diversity of animal associated strains. BMC Microbiol 14:173

52. Hensgens MP, Goorhuis A, Notermans DW, van Benthem BH, Kuijper EJ (2009) Decrease of hypervirulent Clostridium difficile PCR ribotype 027 in the Netherlands. Euro Surveill 14:19402

53. Skraban J, Dzeroski S, Zenko B, Mongus D, Gangi S, Rupnik M (2013) Gut microbiota patterns associated with colonization of different Clostridium difficile ribotypes. PLoS One 8:e58005

54. Rodriguez-Palacios A, Staempfli HR, Duffield T, Weese JS (2007) Clostridium difficile in retail ground meat, Canada. Emerg Infect Dis 13:485-487

55. Rodriguez-Palacios A, Reid-Smith RJ, Staempfli HR, Daignault D, Janecko $\mathrm{N}$, Avery BP, Martin $\mathrm{H}$, Thomspon AD, McDonald LC, Limbago B, Weese JS (2009) Possible seasonality of Clostridium difficile in retail meat, Canada. Emerg Infect Dis 15:802-805

56. Hofer E, Haechler H, Frei R, Stephan R (2010) Low occurrence of Clostridium difficile in fecal samples of healthy calves and pigs at slaughter and in minced meat in Switzerland. J Food Prot 73:973-975

57. Sambol SP, Merrigan MM, Tang JK, Johnson S, Gerding DN (2002) Colonization for the prevention of Clostridium difficile disease in hamsters. J Infect Dis 186:1781-1789 
58. Songer JG, Jones R, Anderson MA, Barbara AJ, Post KW, Trinh HT (2007) Prevention of porcine Clostridium difficile-associated disease by competitive exclusion with nontoxigenic organisms. Vet Microbiol 124:358-361

59. Godden S, Feirtag J, Green L, Wells S, Fetrow J (2003) A review of issues surrounding the feeding of waste milk and pasteurization of waste milk and colostrum. Proceedings of the Minnesota Dairy Health Conference, 2003. College of Veterinary Medicine, University of Minnesota. http://purl. umn.edu/108982 Accessed 27 January 2016

60. Struble AL, Tang YJ, Kass PH, Gumerlock PH, Madewell BR, Silva J Jr (1994) Fecal shedding of Clostridium difficile in dogs: a period prevalence survey in a veterinary medical teaching hospital. J Vet Diagn Invest 6:342-347

61. Yaeger MJ, Kinyon JM, Songer JG (2007) A prospective, case control study evaluating the association between Clostridium difficile toxins in the colon of neonatal swine and gross and microscopic lesions. J Vet Diagn Invest 19:52-59

62. Alvarez-Perez S, Blanco JL, Bouza E, Alba P, Gibert X, Maldonado J, Garcia ME (2009) Prevalence of Clostridium difficile in diarrhoeic and non-diarrhoeic piglets. Vet Microbiol 137:302-305
63. Hammitt MC, Bueschel DM, Keel MK, Glock RD, Cuneo P, DeYoung DW Reggiardo C, Trinh HT, Songer JG (2008) A possible role for Clostridium difficile in the etiology of calf enteritis. Vet Microbiol 127:343-352

64. Slovis NM, Elam J, Estrada M, Leutenegger CM (2014) Infectious agents associated with diarrhoea in neonatal foals in central Kentucky: a comprehensive molecular study. Equine Vet J 46:311-316

65. West JW (2003) Effect of heat-stress on production in dairy cattle. J Dairy Sci 86:2131-2144

66. Bohmanova J, Misztal I, Cole JB (2007) Temperature-humidity indices as indicators of milk production losses due to heat stress. J Dairy Sci 90:1947-1956

67. Norman KN, Harvey RB, Scott HM, Hume ME, Andrews K, Brawley AD (2009) Varied prevalence of Clostridium difficile in an integrated swine operation. Anaerobe 15:256-260

68. Smith DL, Smith T, Rude BJ, Ward SH (2013) Short communication: comparison of the effects of heat stress on milk and component yields and somatic cell score in Holstein and Jersey cows. J Dairy Sci 96:3028-3033

\section{Submit your next manuscript to BioMed Central and we will help you at every step:}

- We accept pre-submission inquiries

- Our selector tool helps you to find the most relevant journal

- We provide round the clock customer support

- Convenient online submission

- Thorough peer review

- Inclusion in PubMed and all major indexing services

- Maximum visibility for your research

Submit your manuscript at www.biomedcentral.com/submit
() Biomed Central 